\title{
Upregulation of zinc transporter 2 in the blood-CSF barrier following lead exposure
}

\author{
Xue Fu ${ }^{1}$, Andrew Zeng ${ }^{1}$, Wei Zheng ${ }^{1}$, and Yansheng $\mathrm{Du}^{1,2}$ \\ ${ }^{1}$ School of Health Sciences, Purdue University, West Lafayette, IN 47907, USA \\ ${ }^{2}$ School of Medicine, Indiana University, Indianapolis, IN 46202, USA
}

\section{Abstract}

Zinc ( $\mathrm{Zn})$ is an essential element for normal brain function; an abnormal $\mathrm{Zn}$ homeostasis in brain and the cerebrospinal fluid (CSF) has been implied in the etiology of Alzheimer's disease (AD). However, the mechanisms that regulate $\mathrm{Zn}$ transport in the blood-brain interface remain unknown. This study was designed to investigate $\mathrm{Zn}$ transport by the blood-CSF barrier (BCB) in the choroid plexus, with a particular focus on $\mathrm{Zn}$ transporter-2 ( $\mathrm{ZnT} 2)$, and to understand if lead $(\mathrm{Pb}$ ) accumulation in the choroid plexus disturbed the $\mathrm{Zn}$ regulatory function in the $\mathrm{BCB}$. Confocal microscopy, quantitative PCR and western blot demonstrated the presence of ZnT2 in the choroidal epithelia; ZnT2 was primarily in cytosol in freshly isolated plexus tissues but more toward the peripheral membrane in established choroidal Z310 cells. Exposure of rats to $\mathrm{Pb}$ (single ip injection of 50mg Pb acetate/kg) for $24 \mathrm{~h}$ increased $\mathrm{ZnT} 2$ fluorescent signals in plexus tissues by confocal imaging and protein expression by western blot. Similar results were obtained by in vitro experiments using Z310 cells. Further studies using cultured cells and a two-chamber Transwell device showed that $\mathrm{Pb}$ treatment significantly reduced the cellular $\mathrm{Zn}$ concentration and led to an increased transport of $\mathrm{Zn}$ across the $\mathrm{BCB}$, the effect that may be due to the increased $\mathrm{ZnT} 2$ by $\mathrm{Pb}$ exposure. Taken together, these results indicate that $\mathrm{ZnT} 2$ is present in the $\mathrm{BCB} ; \mathrm{Pb}$ exposure increases the ZnT2 expression in choroidal epithelial cells by a yet unknown mechanism and as a result, more $\mathrm{Zn}$ ions may be deposited into the intracellular $\mathrm{Zn}$ pool, leading to a relative Zn deficiency state in the cytoplasm at the BCB.

\section{Keywords}

Zinc (Zn); zinc transporter 2 (ZnT2); lead (Pb); blood-CSF barrier; Z310 cells

\section{Introduction}

Zinc $(\mathrm{Zn})$ is an essential element for brain development and function. ${ }^{1-3} \mathrm{Zn}$ deficiency inhibits cell growth and division, while excessive extracellular $\mathrm{Zn}$ level can cause cell death, leading to neuronal degeneration. ${ }^{4-5}$ Involvement of $\mathrm{Zn}$ in Alzheimer's disease (AD) has been recognized since the early 1990s. Both amyloid precursor protein (APP) and betaamyloid $(\mathrm{A} \beta)$ can be characterized as Cu/Zn metalloproteins, with APP in the CSF being more easily precipitated than $A \beta$ peptides. ${ }^{6} \mathrm{Zn}$ can bind to a specific, cysteine-rich region of the APP-695 ecto domain. ${ }^{7,8}$ Noticeably, $\mathrm{Zn}$ (II) is the only physiologically available metal

Copyright $\odot 2013$ by the Society for Experimental Biology and Medicine

Corresponding author: Yansheng Du. ydu@iupui.edu.

Author Contributions: All authors participated in the design, interpretation of the studies and analysis of the data and review of the manuscript. XF and AZ conducted the experiments, WZ and YD supervised experiments and helped write the manuscript. 
ion capable of precipitating $\mathrm{A} \beta$ at $\mathrm{pH}$ 7.4. The exact role of $\mathrm{Zn}$ in $\mathrm{AD}$ etiology remains controversial. Some suggest that $\mathrm{Zn}$ deficiency is one of the risk factors for AD. Significant low levels of $\mathrm{Zn}$ in serum ${ }^{9}$ and cerebrospinal fluid (CSF) ${ }^{10}$ have been found in the patients with AD. The low $\mathrm{Zn}$ extracellular level could be due to $\mathrm{Zn}$ interaction withA $\beta$ and/or APP; the binding of $\mathrm{Zn}$ with proteins may lead to a depletion of extracellular $\mathrm{Zn}$. An increased $\mathrm{Zn}$ level has been found in the aggregated senile plaques. ${ }^{6,7,11}$ Some researchers have also reported that the extracellular $\mathrm{Zn}$ is involved in the amyloidopathy and advanced AD. ${ }^{12,13}$ Clearly, the regulatory mechanisms at the blood, CSF, and brain parenchyma interfaces play an important role in keeping the homeostasis of $\mathrm{Zn}$ in the central nervous system (CNS). However, limited knowledge is currently available on the $\mathrm{Zn}$ regulatory system in brain; even less is known about how brain controls the transport of $\mathrm{Zn}$ by brain barrier systems.

Zinc transporter-2 (ZnT2), a member of the $\mathrm{Zn}$ transporters family, is widely expressed in small intestine, kidney, placenta, pancreas, testis, seminal vesicles, prostate and mammary gland, and functions to transport $\mathrm{Zn}$ from the cytoplasm to the lumen of organelles or the extracellular compartment so as to reduce the intracellular Zn levels. ${ }^{14-19}$ Inside cells, ZnT2 has been found highly express in the vesicles and lysosomes. ${ }^{20}$ The ZnT family possesses a structure with a long loop ion-binding domain containing histidine residues. ${ }^{21,22}$ Liuzzi et al. have clarified that ZnT2 was oriented apically, directly adjacent to the microvilli of the polarized enterocytes. ${ }^{19}$ However, whether ZnT2 existed in the blood-brain barrier (BBB), which separates the blood from brain interstitial fluid, or in the blood-CSF barrier (BCB), which disconnects the blood from the CSF, remain unknown. Noticeably, the BCB is mainly located in the polarized choroid plexus in brain ventricles and functions to produce the CSF and regulate the transport of nutrients and materials including metal ions between blood and CSF. ${ }^{23-25}$ Earlier human autopsy data have shown that the curly fibers and tangles accumulate in the choroid plexus and ependymal layer of $\mathrm{AD}$ patients. ${ }^{26}$ The data in literature and from our own works have also established that the choroid plexus contains APP and soluble $\mathrm{A} \beta$, a source of CSF $A \beta .^{27,28}$

Recently, studies from this group using Tg-SWDI transgenic mice, which genetically overexpress amyloid plaques at age of 2-3 months, show that subchronic exposure to toxic metal, lead $(\mathrm{Pb})$ causes a significant increase of $\mathrm{A} \beta$ in the CSF, brain cortex and hippocampus. Immunohistochemistry displayed a detectable increase of amyloid plaques in brains of $\mathrm{Pb}$-exposed animals. Further studies using synchrotron X-ray fluorescence technique demonstrate a high level of $\mathrm{Pb}$ present in amyloid plaques in mice exposed to $\mathrm{Pb}$ in vivo. ${ }^{29,30}$ These findings support data in the literature that $\mathrm{Pb}$ exposure may increase the risk of $\mathrm{AD} .{ }^{31-35}$ Since $\mathrm{Pb}$ poisoning remains one of the major public health concerns among children and occupational workers, ${ }^{36}$ and since $\mathrm{Pb}$ is known to accumulate in the choroid plexus, ${ }^{25}$ it became interesting to learn if $\mathrm{Pb}$ accumulation in the choroid plexus may interact with $\mathrm{Zn}$ transport systems and affect $\mathrm{Zn}$ homeostasis in the CSF and brain.

The present study was designed to test a novel hypothesis that ZnT2 was expressed in the $\mathrm{BCB}$ in brain choroidal plexus and $\mathrm{Pb}$ exposure may affect the function of ZnT2, thereby interfering with the $\mathrm{Zn}$ transport across the $\mathrm{BCB}$. The findings from this study would enrich the literature on how $\mathrm{Zn}$ is transported by the blood-brain-CSF interfaces and whether $\mathrm{Pb}$ induced amyloid plaque formation has a potential linkage to $\mathrm{Zn}$ regulation by the brain barrier systems. The results shall be of interest to $\mathrm{Zn}$ researchers as well as neurotoxicologists engaged in $\mathrm{Pb}$ research. 


\section{Materials and methods}

\section{Materials}

Lead acetate (PbAc), $\beta$-actin, dithiothreitol (DTT), 2-mer-captoethanol, phenylmethylsulfonyl fluoride (PMSF), polyacrylamide and tetramethyl-ethylenediamine (TEMED), dexamethasone (DEX) and the polyclonal anti-rabbit ZnT2 antibody for immunoblotting were purchased from Sigma Chemicals (St. Louis, MO); Alexa-labeled secondary antibodies (Invitrogen, NY); enhanced chemiluminescene reagent (ECL) from Pierce Endogen (Rockford, IL), Mito-tracker from Invitrogen (Carlsbad, CA); and Dulbecco's modified essential medium (DMEM), fetal bovine serum (FBS), penicillin, streptomycin, gentamycin, and $0.25 \%$ trypsin EDTA from Gibco (Grand Island, NY). All reagents were of analytical grade, HPLC grade or the best available pharmaceutical grade.

\section{Animals and $\mathrm{Pb}$ administration}

Male Sprague-Dawley rats were purchased from Harlan Sprague Dawley Inc. (Indianapolis, IN). At the time of use, the rats were 10 weeks old weighing 220-250 g. Upon arrival, the rats were housed in a temperature-controlled room under a 12-h light/dark cycle and allowed to acclimate for one week prior to experimentation. They had free access to tap water and pellet Purina semi-purified rat chow (Purina Mills Test Diet, 5755C. Purina Mills, Richmond, Inc.). The study was conducted in compliance with animal uses regulation and approved by the Animal Care and Use Committee of Purdue University. PbAc dissolved in sterile saline was administrated to rats by a single ip injection with $0.1 \mathrm{~mL} / \mathrm{kg}$ body weight at the dose of $50 \mathrm{mg} \mathrm{PbAc} / \mathrm{mL}$. The daily equivalent volume of sterile saline was given to the animals in the control group. ${ }^{37-39}$ Twenty-four hours after the injection, rats were anesthetized with ketamine/xylazine (75:10mg/kg, $1 \mathrm{mg} / \mathrm{kg}$ ip). Rat brains were dissected to harvest the choroid plexus tissues from the lateral ventricles for the immunohistochemistry, quantitative real-time RT-PCR (qPCR) and western blot determinations.

\section{Cell culture and treatments}

The choroidal epithelial Z310 cell line was originally developed from murine choroid plexus by this laboratory. The characteristics, culture and maintenance procedures of this cell line were described in previous publications. ${ }^{40}$ In brief, Z310 cells were grown in DMEM medium containing $10 \%$ FBS, 10,000 U penicillin/mL, 10,000 $\mu$ g streptomycin/mL, 50mg/ $\mathrm{mL}$ Gentamicin sulfate, and 10ng/mL EGF), in a humidified incubator with $95 \%$ air-5\% $\mathrm{CO}_{2}$ at $37^{\circ} \mathrm{C}$.

Autoclaved $5 \mathrm{mM} \mathrm{PbAc}$ stocking solution was prepared by dissolving $\mathrm{PbAc}$ in sterile double-deionized water. The cells were treated with the working concentration of $5 \mu \mathrm{M}$ $\mathrm{PbAc}$ for $24 \mathrm{~h}$ to determine localization and expression of ZnT2. Z310 cells were also treated with $100 \mathrm{nM}$ DEX in the culture medium for $24 \mathrm{~h}$ to upregulate the expression level of ZnT2. ${ }^{41}$ At the end of the treatments, cells were collected for further protein and total RNA isolations.

\section{Immunohistochemistry}

The glass coverslips were sterilized with $75 \%$ ethanol, rinsed and placed in a six-well plate. The Z310 cells were seeded at a density of $3 \times 10^{5} /$ well, allowed to grow for $24 \mathrm{~h}$ to achieve $80 \%$ confluence, and then treated with $5 \mu \mathrm{M} \mathrm{PbAc}$ and $100 \mathrm{nM}$ DEX for another $24 \mathrm{~h}$. At the end of treatment, the cells were fixed in $4 \%$ paraformaldehyde and permeabilized in $0.1 \%$ Triton X-100 at room temperature, followed by three washes with PBS in between each step. Cells were then blocked with $1 \%$ bovine serum albumin (BSA) for $1 \mathrm{~h}$ followed by overnight incubation with polyclonal anti-rabbit ZnT2 primary antibody $(1: 1000)$ at $4{ }^{\circ} \mathrm{C}$ After a $1 \mathrm{~h}$ incubation with Fluor Alexa-488 conjugated secondary antibody (1:1000) at 
room temperature, the glass coverslips were mounted using Gold Anti-Fade reagent (Invitrogen, Carlsbad, CA) and dried overnight for further observation using the confocal microscopy.

\section{Confocal microscopic study}

To acquire images, prepared slides were mounted on the stage of a Nikon inverted confocal laser-scanning microscope and viewed through a 60x oil-immersion objective (Plan Apo, $60 \times / 1.40$ oil, $\infty 0.17, \mathrm{Ph} 3 \mathrm{DM})$, with a $488 \mathrm{~nm}$ laser line for excitation. Lower laser intensity was used to avoid photo bleaching. Each slide was examined under reduced, transmitted light illumination and an area containing undamaged epithelium with underlying vasculature was selected.

\section{Quantitative real-time RT-PCR}

The mRNA level encoding ZnT2 was quantified using qPCR. The total RNA was isolated from Z310 cells using the TRIzol reagent. An aliquot of $0.5 \mu \mathrm{g}$ RNA was reversetranscribed into cDNA. iTaq Universal SYBR Green Supermix (BioRad, CA) was used for qPCR analyses. The amplification was run in the CFX connect TM real-time PCR detection system (BioRad, CA). With an initial 3-min denaturation at $95^{\circ} \mathrm{C}$, the amplification program was followed by 40 cycles of $30 \mathrm{~s}$ denaturation at $95^{\circ} \mathrm{C}, 10 \mathrm{~s}$ gradient 55.0 to $65.0^{\circ} \mathrm{C}$ and 30 $\mathrm{s}$ extension at $72^{\circ} \mathrm{C}$. Each real-time RT-PCR reaction was run in triplicate. The forward and reverse primers for the $\mathrm{ZnT} 2$ gene were designed using Primer Express 3.0 software. Primers sequences for rat ZnT2 used in this study were forward primer 5'-AAG TAC GTG GAC CCC ATC TG-3' and a reverse primer 5'-CCC TTC CAT GAG AAC CAA GA-3' (GenBank accession no. NM_052803.1). And the rat glyceraldehydes-3-phos-phate dehydrogenase (GAPDH), used as an internal control, had a forward primer 5'-CCT GGA GAA ACC TGC CAA GTAT-3' and a reverse primer 5'-AGC CCA GGA TGC CCT TTA GT-3' (Genbank Accession No. NM_017008). ${ }^{42,43}$ The relative differences in gene expression between groups were expressed using cycle time $(\mathrm{Ct})$ values; these $\mathrm{Ct}$ values of interested genes were first normalized with the GAPDH of the same sample, and then the relative differences between control and treatment groups were calculated and expressed as relative increases, setting the control as $100 \%$.

\section{Western blot analyses}

Total cellular proteins from Z310 cells were extracted in homogenization buffer containing 20mM Tris, pH 7.5, 5mM EGTA, $1 \%$ Triton X-100, 1\% SDS, Protease Inhibitor Cocktail (Calbiochem, San Diego, CA). Samples were sonicated and quantified for protein concentrations using a Bradford assay. A volume of protein extracts (100 $\mu \mathrm{g}$ of protein) was mixed with an equal volume of $2 \times$ sample buffer, loaded on a $12 \%$ SDS-PAGE gel, electrophoresed and transferred to a polyvinylidene difluoride (PVDF) membrane. The membrane was blocked with 5\% milk in Tris-buffered saline with Tween 20 and incubated with a primary antirabbit polyclonal ZnT2 $(42 \mathrm{kDa})$ antibody $(1: 100)$ at $4^{\circ} \mathrm{C}$ overnight, followed by a stain with a horseradish-peroxidase-conjugated goat anti-rabbit IgG antibody $(1: 3000)$ at room temperature for $1 \mathrm{~h}$ and developed using ECL. $\beta$-actin $(42 \mathrm{kDa})$ was used as an internal control. The optical density (OD) of the blot band intensity was further quantified using Image $J$ and reported in the OD ratio of $\mathrm{ZnT} 2 / \beta$-actin.

\section{Cellular $\mathrm{Zn}$ retention study}

Z310 cells were seeded in 6-well plates at a density of $3 \times 10^{5}$ cells/well for $24 \mathrm{~h}$, followed by the treatments with $5 \mu \mathrm{M} \mathrm{PbAc}$ and $100 \mathrm{nM}$ DEX for an additional 24h. At the end of the treatments, cells were incubated with final concentration of $3 \mu \mathrm{M} \mathrm{ZnCl}_{2}$ in the Hank's balanced salt solution (HBSS) for $1 \mathrm{~h}$ and then harvested followed by three washes with 
PBS to remove excessive $\mathrm{Zn}$. Intracellular $\mathrm{Zn}$ levels were determined using atomic absorption spectrophotometry (AAS) after the measurement of protein quantity. All samples were digested with concentrated nitric acid in an oven at $55^{\circ} \mathrm{C}$, overnight. A Varian Spectra AA-20 Plus GTA-96 flameless graphite furnace AAS was used to quantify Zn concentrations in the $\mathrm{Z} 310$ cells. Digested samples were diluted with $1.0 \%$ (v/v) $\mathrm{HNO}_{3}$ for $\mathrm{Zn}$ measurement in order to keep the reading within the concentration range of the standard curve. The ranges of calibration standards were $0-2.5 \mu \mathrm{g} / \mathrm{L}$ for $\mathrm{Zn}$ and the detection limits for $\mathrm{Zn}$ was $0.9 \mathrm{ng} / \mathrm{mL}$ of the assay solution.

\section{Two-chamber transwell system using primary choroid plexus cells}

The method to culture primary choroidal epithelial cells has been described in previous publications in this laboratory ${ }^{27,44-46}$ Rats aged four weeks were sacrificed to harvest choroid plexus tissues. These tissues were digested in HBSS containing $0.2 \%$ pronase at $37^{\circ} \mathrm{C}$ for $10-15 \mathrm{~min}$, followed by two washes with HBSS, and then re-suspended in growth DMEM medium containing 10\% FBS, 100 units $/ \mathrm{mL}$ penicillin, $100 \mu \mathrm{g} / \mathrm{mL}$ streptomycin, $0.25 \mu \mathrm{g} / \mathrm{mL}$ amphotericin, $100 \mu \mathrm{g} / \mathrm{mL}$ gentamycin, and $10 \mathrm{ng} / \mathrm{mL}$ EGF. A 20 -gauge needle was used to pass cells through 14-15 times to ensure adequate cell separation for seeding. Cells stained with $0.4 \%$ Trypan blue were counted under a light microscope to determine the cell numbers; the cells were then seeded on 35-mm Petri dishes (pre-coated with $0.01 \%$ collagen) at a density of $2-3 \times 10^{5}$ cells $/ \mathrm{mL}$. The cultured cells were maintained at $37^{\circ} \mathrm{C}$ with $95 \%$ air-5\% $\mathrm{CO}_{2}$ in a humidified incubator without disturbance for at least $48 \mathrm{~h}$. The growth medium was replaced three days after the initial seeding and every two days thereafter.

After cultured in dishes for 7-10 days, the cells were transferred to the inner chamber of a Transwell transport device. The inner chamber, also known as the apical chamber, is immersed in the outer chamber. An aliquot of $0.8 \mathrm{~mL}$ cell suspension $\left(10 \times 10^{5}\right.$ cells $/ \mathrm{mL}$ for initial seeding) was added to the inner chamber and $1.2 \mathrm{~mL}$ of medium was added to the outer chamber. The transepithelial electrical resistance (TEER), an indicator of the tightness of the barrier, was used to track the formation of a cellular monolayer between the inner and outer chambers. The TEER value was measured every other day by an Epithelial VoltOhmmeter (EVOM, World Precision Instruments, Sarasota, FL) until the resistance reached $50-60 \Omega / \mathrm{cm}^{2}$. The same twochamber system without cells was used as the blank and its background was subtracted from the measured TEER. When the cells grew to a confluence, the surface level of the medium in the inner chamber was roughly $2 \mathrm{~mm}$ above the outer chamber. This in vitro system mimicking the $\mathrm{BCB}$ has been used in our previous studies. $27,37,46-48$

\section{In vitro transepithelial transport of $\mathrm{Zn}$}

To investigate the transport direction of $\mathrm{Zn}$ across the $\mathrm{BCB}$, the primary cells cultured in the Transwell devices were randomly divided into three groups: the control group without any treatment, the $\mathrm{Pb}$-exposed group (5 $\mu \mathrm{M} \mathrm{PbAc}, 24 \mathrm{~h})$, and the DEX-induced group (100nM DEX, 24h). At the end of treatment, an aliquot of $0.8 \mathrm{~mL} \mathrm{HBSS}$ containing the mixture of $\mathrm{ZnCl}_{2}$ and ${ }^{14} \mathrm{C}$-sucrose to the final concentrations of $3 \mu \mathrm{M} \mathrm{ZnCl}_{2}$ and $0.1 \mu \mathrm{Ci} / \mathrm{mL}^{14} \mathrm{C}$ sucrose was added to the inner chamber (donor chamber), and an aliquot of 1.2-mL HBSS was added to the outer chamber (receiver chamber). A series of time points $(0,5,10,15,30,60,90 \mathrm{~min}$, and 2, 3, and $4 \mathrm{~h})$ was set for sample collection. At each time, an aliquot of $10 \mu \mathrm{L}$ medium from both chambers was collected and replaced with an equal volume of the counterpart medium. The concentration and radioactivity were measured in the outer chamber to determine the efflux of $\mathrm{Zn}$ from the CSF to blood. Zn concentrations of all samples were measured using AAS. To count the ${ }^{14} \mathrm{C}$-sucrose, the samples were mixed 
with Eco-lite scintillation cocktail and counted on a Packard Tr-Carb 2900 TR Liquid Scintillation Analyzer.

To determine the permeability constants for $\mathrm{Zn}$ and $\mathrm{C}$-sucrose transport across the cellular monolayer, the data within the linear range of the time course were used for linear regression analyses. The slope ( $\mathrm{Zn} \mathrm{ng} / \mathrm{mL} / \mathrm{min}$ and ${ }^{14} \mathrm{C}$-sucrose dp.m./mL/min) of each dataset was used to calculate the total and blank permeability coefficients in equation (1):

$$
\mathrm{P}_{\mathrm{T}} \operatorname{orP}_{\mathrm{B}}=\frac{\mathrm{V}_{\mathrm{R}}}{\mathrm{A} \times \mathrm{C}_{\mathrm{D}}} \times \frac{\Delta \mathrm{C}_{\mathrm{R}}}{\Delta \mathrm{t}}
$$

where $\mathrm{P}_{\mathrm{T}}$ is the total (cell monolayer + membrane) permeability coefficient $(\mathrm{cm} / \mathrm{min}) ; \mathrm{P}_{\mathrm{B}}$ is the blank permeability coefficient $(\mathrm{cm} / \mathrm{min}) ; \mathrm{V}_{\mathrm{R}}$ is the volume of the receiver $\left(\mathrm{ml} \mathrm{or} \mathrm{cm}^{3}\right)$; $\mathrm{A}$ is the surface area of transport membrane in the inner chamber $\left(\mathrm{cm}^{2}\right) ; \mathrm{C}_{\mathrm{D}}$ is the concentration in donor chamber $(\mathrm{mg} / \mathrm{mL})$; and $\Delta \mathrm{C}_{\mathrm{R}} / \Delta \mathrm{t}$ is the changes of concentration in the receiver over a fixed time period $(\mathrm{mg} / \mathrm{mL} / \mathrm{min})$. Thus, the permeability or flux coefficient of metals $\left(\mathrm{P}_{\mathrm{E}}\right)$ can be obtained from equation (2):

$$
\frac{1}{\mathrm{P}_{\mathrm{E}}}=\frac{1}{\mathrm{P}_{\mathrm{T}}}-\frac{1}{\mathrm{P}_{\mathrm{B}}}
$$

where $\mathrm{P}_{\mathrm{E}}$ is the permeability coefficient of $\mathrm{Zn}$ or ${ }^{14} \mathrm{C}$-sucrose transport across the epithelial barrier.

\section{Statistical analysis}

Statistical analyses of the differences between groups were carried out by one-way ANOVA with post hoc comparisons by Dunnett's test or Student t-tests using SPSS for Windows (version 19.0). All data are expressed as mean \pm SD. The differences between two means were considered significant if $p$ values were equal to or less than 0.05 .

\section{Results}

\section{Expression of $\mathrm{ZnT2}$ in the choroid plexus tissues and effects of in vivo $\mathrm{Pb}$ exposure}

To determine the existence of $\mathrm{ZnT} 2$ in the BCF barrier, the choroid plexus tissues from rat lateral ventricles were dissected and stained with ZnT2 primary antibody. As shown in Figure 1(A/a), ZnT2 was distinctly expressed in the choroid plexus and primarily concentrated close to the apical border with a small portion along the basolateral membrane in the choroidal epithelial cells.

After rats received a single ip injection of $50 \mathrm{mg} \mathrm{PbAc} / \mathrm{kg}$ for $24 \mathrm{~h}$, it was interesting to observe much stronger intensities of ZnT-2 associated fluorescent signals at the apical microvilli surface of choroid plexus epithelia than the control tissue (Figure 1A/d). This finding prompted us to investigate and quantify $\mathrm{Pb}$ effect on $\mathrm{ZnT} 2$ expression. The qPCR and western blot were used quantify the mRNA and protein expression levels of ZnT2, respectively, in the choroid plexus tissue collected from $\mathrm{Pb}$-exposed and control rats. The mRNA level of ZnT2 as normalized by the housekeeping gene GAPDH was significantly increased to about $20 \%$ following $\mathrm{Pb}$ exposure when compared with the control $(P<0.05)$ (Figure 1B). Consistent with qPCR results, the western blots also showed the ZnT2 protein expression in plexus tissues collected fromanimals treated with $\mathrm{Pb}$ was $46 \%$ higher than that in control tissues $(P<0.05)$ (Figure 1(C) and (D)). 


\section{Expression of $\mathrm{ZnT2}$ in choroidal $\mathrm{Z310}$ cells following $\mathrm{Pb}$ exposure, in vitro}

To study $\mathrm{Pb}$ effect on $\mathrm{ZnT2}$, it was necessary to choose a $\mathrm{Pb}$ concentration that did not cause the substantial cell killing. The cells were incubated with 5, 100, and $250 \mu \mathrm{M} \mathrm{PbAc}$ for $24 \mathrm{~h}$ and cell viability was determined by counting the live cell numbers. The data in Figure 2(a) showed that at the concentrations of 100 and $250 \mu \mathrm{M}$ PbAc treatments caused a substantial reduction in cell numbers under the light microscope. The total cell numbers were significantly reduced in these two dose groups while they were unchanged in the group treated with $5 \mu \mathrm{M} \mathrm{PbAc}$ (Figure $2 \mathrm{~b}$ ). Thus, in the subsequent in vitro experiments, $\mathrm{PbAc}$ concentration of $5 \mu \mathrm{M}$ was used.

When the Z310 cells were stained with the ZnT2 primary antibody, the confocal microscopic observation revealed that $\mathrm{ZnT} 2$ was present in choroidal Z310 cells. Similar to the choroid tissue, the stains for ZnT2 in cultured control cells, while mainly in the cytoplasm, were distributed proximally to the plasma membrane (Figure 3A/a). Following treatment of Z310 cells with $5 \mu \mathrm{M} \mathrm{PbAc}$ for $24 \mathrm{~h}$, the $\mathrm{ZnT} 2$ fluorescent signals were visibly stronger in $\mathrm{Pb}$-treated cells than controls and highly concentrated close to the plasma membrane with a small amount scattered in the cytosolbut not in the nuclei (Figure 3A/d). The qPCR analyses showed about 60\% increase in ZnT2 mRNA expression in Pb-treated cells as compared with the control $(P<0.05)$ (Figure 3B). The protein expression level of $\mathrm{ZnT} 2$ was also significantly increased following $\mathrm{Pb}$ exposure when compared with the control $(P<0.01)$ (Figure 3(C) and (D)). These results demonstrate that ZnT2 exists in the choroidal Z310 cells and $\mathrm{Pb}$ exposure appears to upregulate the expression of ZnT2.

As a positive control, we chose the glucocorticoid analog DEX to verify the expression of ZnT2 in the Z310 cells, since DEX is known capable of upregulating the expression of ZnT2 in various cell lines (i.e. rat AR42J acinar cells). After the Z310 cells were incubated with $100 \mathrm{nM}$ DEX for $24 \mathrm{~h}$, confocal images revealed a greatly increased fluorescent intensityin the treated cells (Figure 4A). Noticeably, the increased signals were not only highly concentrated along the cell membrane but also around the central nucleus. Both qPCR and western blot measurements verified significant increases in ZnT2 mRNA ( 40\%) and protein expression $(\sim 70 \%)$, respectively, in cells treated with DEX than control cells $(P<0.01)$ (Figure $4(\mathrm{~B})$ to $(\mathrm{D}))$. The data suggest that DEX effectively increases the expression of ZnT2 in choroidal epithelial cells as it does to other cell types.

\section{Cellular $\mathrm{Zn}$ concentrations after in vitro $\mathrm{Pb}$ treatment}

Since ZnT2 functions to export the intracellular Zn to extracellular matrices, we hypothesized that the intracellular $\mathrm{Zn}$ concentration in $\mathrm{Pb}$-treated $\mathrm{Z} 310$ cells would be decreased due to the elevated $\mathrm{ZnT} 2$ expression. To test this hypothesis, $\mathrm{Z} 310$ cells were incubated with $5 \mu \mathrm{M} \mathrm{PbAc}$ and $100 \mathrm{nM}$ DEX (as a positive control) for $24 \mathrm{~h}$, followed by incubation with the HBSS containing $3 \mu \mathrm{M} \mathrm{ZnCl}_{2}$ for $1 \mathrm{~h}$. After thoroughly washing the cells with PBS to remove the extracellular Zn, the cells were collected for AAS analysis of cellular $\mathrm{Zn}$ concentrations. The results in Figure 5 revealed that the intracellular $\mathrm{Zn}$ concentration in control cells was $631 \mathrm{ng} \mathrm{Zn/g}$ protein, which was significantly higher than those in $\mathrm{Pb}$-treated (460 ng Zn/g protein, $P<0.01$ ) or DEX-treated cells $(516 \mathrm{ng} \mathrm{Zn/g}$ protein, $P<0.05$ ), suggesting that the increased expression of ZnT2 may be one of the potential mechanisms that led to the deficiency of intracellular $\mathrm{Zn}$ in choroidal cells.

\section{Transepithelial Zn transport studies}

The primary culture of choroid plexus epithelial cells was used in a two-chamber Transwell system to determine the $\mathrm{Pb}$ effect on the transepithelial transport of $\mathrm{Zn}$. The formation of a complete monolayer barrier between two chambers was noticed about 12 days in the culture by microscope observation and also by the TEER values, which reached about $50-65 \Omega / \mathrm{cm}$ 
(Figure 6A). The TEER value was significantly decreased in cells treated with $5 \mu \mathrm{M} \mathrm{Pb}$, so were cells treated with DEX (Figure 6B); however, this reduction in TEER values did not seem to cause the structural leakage of the barrier, since the permeability constant $\left(\mathrm{P}_{\mathrm{E}}\right)$ values for the space marker $\mathrm{C}$-sucrose did not change in $\mathrm{Pb}$ - and DEX-treated cells (Table 1).

In the control group, when $\mathrm{Zn}$ was added to the donor (inner) chamber and monitored in the receiver (outer) chamber, the transport of $\mathrm{Zn}$ across the $\mathrm{BCB}$ after correcting for the space marker of ${ }^{14} \mathrm{C}$-sucrose had the transepithelial permeability constant of $\mathrm{P}_{\mathrm{E}}=(18.34 \pm 2.26) \times$ $10^{-4} \mathrm{~cm} / \mathrm{min}$ (Table 1). In the $\mathrm{Pb}$ - and DEX-exposed groups, the $\mathrm{P}_{\mathrm{E}}$ values of $\mathrm{Zn}$ across the monolayer were $(35.50 \pm 6.38)$ and $(25.65 \pm 6.79) \times 10^{-4} \mathrm{~cm} / \mathrm{min}$, respectively, which were significantly increased as compared with the control (Table 1 ). The data appeared to suggest that $\mathrm{Pb}$ exposure decreased cellular retention of $\mathrm{Zn}$ in the $\mathrm{BCB}$ and increased the $\mathrm{Zn}$ transport across the $\mathrm{BCB}$; the effect may be a consequence of the elevated intracellular $\mathrm{ZnT} 2$ in choroidal epithelial cells following the $\mathrm{Pb}$ exposure.

\section{Discussion}

$\mathrm{ZnT} 2$ was first found in the membranes of intracellular vesicles in the $\mathrm{Zn}$-sensitive BHK cell line, ${ }^{49}$ intestine epithelia, and pancreatic acinar cells ${ }^{14}$, where $\mathrm{ZnT} 2$ functions to confer resistance to $\mathrm{Zn}$ by facilitating $\mathrm{Zn}$ transport from the cytosol into the vesicle called zincosome for sequestration in order to maintain the cellular $\mathrm{Zn}$ homeostasis. ${ }^{50}$ The results presented in this study clearly demonstrate that ZnT2 exists in the choroid plexus, where the $\mathrm{BCB}$ is located. In freshly isolated plexus tissues, $\mathrm{ZnT} 2$ is present proximally to the apical brush border and basolateral membrane of the choroidal epithelia. Similarly, in the established choroidal epithelial Z310 cells, ZnT2 also appears to distribute peripherally toward the plasma membrane. These findings were consistent with previous studies which also observed apical localizations of ZnT2 isoforms in rat mammary and intestine epithelial cells. ${ }^{14,51} \mathrm{~Pb}$ exposure, either in vivo or in vitro, apparently induces the $\mathrm{ZnT} 2$ expression in the choroid plexus; consequently $\mathrm{Pb}$ exposure causes intracellular $\mathrm{Zn}$ deficiency.

Earlier reports in literature have shown the presence of a number of $\mathrm{Zn}$ transporters in rodent choroid plexus including ZnT1, ZnT3, ZnT4, ZnT6, ZnT7, zip1, and zip4. ${ }^{52-54}$ Studies by Bobilya et al. show the expression of ZnT2 in a BBB model using porcine brain capillary endothelial cells (BCEC); when the intracellular Zn concentration was maintained at a high level, the ZnT2 expression was elevated, suggesting that ZnT2 may be involved in Zn transport by the BBB and play a role in maintaining brain $\mathrm{Zn}$ homeostasis. ${ }^{55}$ The current studies by using confocal microscopy, qPCR and western blot demonstrated the presence of $\mathrm{ZnT} 2$ in rat choroid plexus tissues and choroidal $\mathrm{Z} 310$ cell line. Thus, in addition to the $\mathrm{BBB}$, the $\mathrm{BCB}$ appears to play a role in regulating $\mathrm{Zn}$ transport between the blood and CSF. Our observation raises more interesting questions for future investigation. For example, what is the relative contribution of the $\mathrm{BBB}$ and $\mathrm{BCB}$ in regulating brain $\mathrm{Zn}$ concentrations? To which direction do the BBB and BCB transport $\mathrm{Zn}$ molecules? How do the function and efficacy of each $\mathrm{Zn}$ transporter in the BCB in their own unique role regulate the $\mathrm{Zn}$ uptake, storage and transpassing in or across the barrier?

Existing literature has established that $\mathrm{Pb}$ exposure interferes with the metabolism of $\mathrm{Zn}$ in blood, kidney, liver, spleen, testes, bone and brain, leading to a decreased cellular $\mathrm{Pb}$ accumulation. ${ }^{56-58}$ Investigations in occupationally $\mathrm{Pb}$-exposed workers also show a significant decrease in blood $\mathrm{Zn}$ levels in Pb-exposed workers. ${ }^{59,60} \mathrm{In}$ contrast, increased dietary intake of $\mathrm{Zn}$ can compete with $\mathrm{Pb}$ for binding sites on a metallothionein-like protein in the gastrointestinal tract, thereby reducing $\mathrm{Pb}$ absorption and subsequently decreasing $\mathrm{Pb}$ toxicity. ${ }^{61-64} \mathrm{As} \mathrm{Zn}$ is a required cofactor for several enzymes such as metallothionein, $\delta$ - 
aminolevulinic acid dehydratase ( $\delta$-ALAD) and superoxide dismutase (SOD), $\mathrm{Pb}$ may interact with $\mathrm{Zn}$ in these enzymes for the similar chemical characteristics of both divalent metals. Our current data clearly showed that exposure to $\mathrm{Pb}$, either in vivo or in vitro, caused a significant increase of $\mathrm{ZnT} 2$ in the $\mathrm{BCB}$. The precise mechanism by which $\mathrm{Pb}$ exposure induces the upregulation of $\mathrm{ZnT} 2$ remains elusive. As $\mathrm{Pb}$ exposure induced the expression of $\mathrm{ZnT}$, presumably, more $\mathrm{Zn}$ may be shifted into intracellular vesicles resulting in a state of relative $\mathrm{Zn}$ deficiency in cells. An indepth investigation is thus warranted for future mechanistic exploration. As the function of $\mathrm{ZnT} 2$ is to export $\mathrm{Zn}$, it is reasonable to postulate that increased ZnT2 may expel the intracellular $\mathrm{Zn}$ and result in a reduction of $\mathrm{Zn}$ within BCB cells. Our in vitro $\mathrm{Zn}$ retention study proved that incubating primary choroidal epithelial cells with $\mathrm{Pb}$ led to a significant reduction of cellular $\mathrm{Zn}$. Hence, $\mathrm{Pb}$ effect on $\mathrm{ZnT} 2$ appears to induce, at least in part, the cellular deficiency of $\mathrm{Zn}$ in the choroid plexus.

Since the BCB separates two distinct fluid compartments, i.e. the blood and CSF, it became interesting to see whether $\mathrm{Pb}$-induced $\mathrm{ZnT} 2$ upregulation ultimately affected the $\mathrm{Zn}$ transepithelial transport. Our two-chamber Transwell experiments with primary culture of choroidal epithelial cells showed a significant increase (but not decrease) of $\mathrm{Zn}$ transport across the monolayer of choroidal epithelia, suggesting that the major transport orientation of $\mathrm{ZnCl}_{2}$ across the $\mathrm{BCB}$ is in an efflux manner from the CSF to the blood circulation. Two early studies found that $\mathrm{Zn}$ uptake into the rat brain across cerebral capillaries was about 20 $\mathrm{nmol} /$ day/brain, while that across the choroid plexus was less than $0.2 \mathrm{nmol} / \mathrm{day} / \mathrm{brain}$, as a consequence of the low influx rate across the BCB, the normal $\mathrm{Zn}$ level in CSF is $0.15 \mu \mathrm{M}$, only accounts for about $1 \%$ that of plasma. ${ }^{65-69}$ These findings suggest that the major supply path for $\mathrm{Zn}$ is via the $\mathrm{BBB}$, whereas the choroid plexus may involve in a slow supply for $\mathrm{Zn}$ to the brain. ${ }^{70-72} \mathrm{ZnT2}$ acts to transport $\mathrm{Zn}$ molecules into intracellular vesicles for storage. The work by Bobilya and his colleagues shows evidence that ZnT2 in the BBB may sequester $\mathrm{Zn}$ into intracellular vesicles and therefore limit $\mathrm{Zn}$ transport across the BBB. ${ }^{55}$ From the clinical point of view, a significantly lower CSF Zn concentration has been found in $\mathrm{AD}$ patients than that of matched controls. ${ }^{10}$ Constantinidis and colleagues also hypothesize that the formation of neurofibrillary tangles observed in AD patients could be due to the deficiency of Zn-containing enzymes including DNA metabolizing Zn enzymes, glutamate dehydrogenase, ${ }^{73,74} \mathrm{SOD}$, carbonic anhydrase, and lactate dehydrogenase. Since the $\mathrm{BCB}$ produces and regulates the bulk of $\mathrm{CSF}$, it would be highly interesting to explore how exactly the $\mathrm{BCB}$ regulates the $\mathrm{Zn}$ homeostasis in the CSF as well as brain extracellular fluid compartments.

In summary, this study provides the evidence of the presence of ZnT2 in the cytosol of choroidal epithelial in the BCB, and ZnT2 appears to expel intracellular Zn molecules to extracellular space, hence transporting $\mathrm{Zn}$ across the $\mathrm{BCB}$. Pb exposure significantly upregulates ZnT2 mRNA and protein expression; expelling Zn out of the cells by ZnT2 may subsequently lead to anintracellular $\mathrm{Zn}$ deficiency. The questions as to how ZnT2 regulates $\mathrm{Zn}$ transport across the $\mathrm{BCB}$, how $\mathrm{Pb}$ exposure, via interference with $\mathrm{Zn}$ transport by the $\mathrm{BCB}$, may affect $\mathrm{Zn}$ homeostasis in brain, and how it may be relevant to the development of $\mathrm{AD}$ would become interesting research topics for future investigation.

\section{Acknowledgments}

This study was partly supported by US NIH/National Institute of Environmental Health Sciences Grant RO1 ES008164 and R21 ES103487.

\section{REFERENCES}

1. Colvin RA, Davis N, Nipper RW, Carter PA. Zinc transport in the brain: routes of zinc influx and efflux in neurons. J Nutr. 2000; 130:1484S-1487S. [PubMed: 10801963]

Exp Biol Med (Maywood). Author manuscript; available in PMC 2015 February 01. 
2. Prasad, AS. The role of zinc in brain and nerve functions. In: Connor, editor. Metals and oxidative damage in neurological disorders. New York, NY: Plenum Press; 1997. p. 95-111.

3. Takeda A. Zinc homeostasis and functions of zinc in the brain. BioMetals. 2001; 14:343-351. [PubMed: 11831464]

4. Kim YH, Park JH, Hong SH, Koh JY. Nonproteolytic neuroprotection by human recombinant tissue plasminogen activator. Science. 1999; 284:647-650. [PubMed: 10213688]

5. Kim EY, Koh JY, Kim YH, Sohn S, Joe E, Gwag BJ. Zn ${ }^{2+}$ entry produces oxidative neuronal necrosis in cortical cell cultures. Eur J Neurosci. 1999; 11:327-334. [PubMed: 9987035]

6. Brown AM, Tummolo DM, Rhodes KJ, Hofmann JR, Jacobsen JS, Sonnenberg-Reines J. Selective aggregation of endogenous B-amyloid peptide and soluble amyloid precursor protein in cerebrospinal fluid by zinc. J Neurochem. 1997; 69:1204-1212. [PubMed: 9282944]

7. Bush AI, Pettingell WH, Multhaup G, Paradis MD, Vonsattel JP, Gusella JF, Beyreuther K, Masters CL, Tanzi RE. Rapid induction of Alzheimer AB amyloid formation by zinc. Science. 1994; 265:1464-1467. [PubMed: 8073293]

8. Cuajungco MP, Faget KY. Zinc takes the center stage: its paradoxical role in Alzheimer's disease. Brain Res Rev. 2003; 41:44-56. [PubMed: 12505647]

9. Brewer GJ, Kanzer SH, Zimmerman EA, Molho ES, Celmins DF, Heckman SM, Dick R. Subclinical zinc deficiency in Alzheimer's disease and Parkinson's disease. Am J Alzheimer's Dis Other Demen. 2010; 25:572-575. [PubMed: 20841345]

10. Molina JA, Jimenez-Jimenez FJ, Aquilar MV, Mesequeer I, Mateos-Vega CJ, Gonzalez-Munoz MJ, de Bustos F, Porta J, Qrti-Pareja M, Zurdo M, Barrios E, Martinez-Para MC. Cerebrospinal fluid levels of transition metals in patients with Alzheimer's disease. J Neural Transm. 1998; 105:479-488. [PubMed: 9720975]

11. Lovell MA, Robertson JD, Teesdale WJ, Campbell JL, Markesbery WR. Copper, iron and zinc in Alzheimer's disease senile plaques. J Neuro Sci. 1998; 158:47-52.

12. Friedlich A, Lee J, van Groen T, Cherny R, Volitakis I, Cole T, Palmiter R, Koh J, Bush A. Neuronal zinc exchange with the blood vessel wall promotes cerebral amyloid angiopathy in an animal model of Alzheimer's disease. J Neurosci. 2004; 24:3453-3459. [PubMed: 15056725]

13. Religa D, Strozyk D, Cherny RA, Volitakis I, Haroutunian V, Winblad B, Naslund J, AI B. Elevated cortical zinc in Alzheimer disease. Neurology. 2006; 67:69-75. [PubMed: 16832080]

14. Liuzzi JP, Cousins RJ. Mammalian zinc transporters. Annu Rev Nutr. 2004; 24:151-172. [PubMed: 15189117]

15. Lopez V, Kelleher SL. Zinc transporter-2 (ZnT2) variants are localized to distinct subcellular compartments and functionally transport zinc. Biochem J. 2009; 422:43-52. [PubMed: 19496757]

16. Palmiter RD, Cole TB, Findley SD. ZnT-2, a mammalian protein that confers resistance to zinc by facilitating vesicular sequestration. EMBO J. 1996; 15:1784-1791. [PubMed: 8617223]

17. Cousins RJ, Liuzzi JP, Lichten LA. Mammalian zinc transport, trafficking, and signals. J Biol Chem. 2006; 281:24085-24089. [PubMed: 16793761]

18. Iguchi K, Usui S, Inoue T, Suqimura Y, Tatematsu M, Hirano K. High-level expression of zinc transporter-2 in the rat lateral and dorsal prostate. J Androl. 2002; 23:819-824. [PubMed: 12399528]

19. Luizzi JP, Bobo JA, Cui L, McMahon RJ, Cousins RJ. Zinc transporters 1, 2 and 4 are differenctially expressed and localized in rats during pregnancy and lactation. J Nutr. 2003; 133:342-351. [PubMed: 12566465]

20. Liuzzi JP, Bobo JA, Lichten LA, Samuelson DA, Cousins RJ. Responsive transporter genes within the murine intestinal-pancreatic axis form a basis of zinc homeostasis. Proc Natl Acad Sci USA. 2004; 101:14355-14360. [PubMed: 15381762]

21. Seve M, Chimienti F, Devergnas S, Favier A. In silico identification and expression of SLC30 family genes: an expressed sequence tag data mining strategy for the characterization of zinc transporters' tissue expression. BMC Genomics. 2004; 5:32. [PubMed: 15154973]

22. Murgia C, Vespignani I, Cerase J, Nobili F, Perozzi G. Cloning, expression, and vesicular localization of zinc transporter Dri 27/ZnT4 in intestinal tissue and cells. Am J Physiol. 1999; 277:G1231-G1239. [PubMed: 10600821] 
23. Zheng, W. Choroid plexus and metal toxicity. In: Chang, LW., editor. Toxicology of metals. Boca Raton: CRC Press; 1996. p. 605-622.

24. Zheng W. Toxicology of choroid plexus: special reference to metalinduced neurotoxicities. Microsc Res Tech. 2001; 52:89-103. [PubMed: 11135452]

25. Zheng W, Aschner M, Ghersi-Egea JF. Brain barrier systems: a new frontier in metal neurotoxicological research. Invited Review. Toxicol Appl Pharmacol. 2003; 192:1-11. [PubMed: 14554098]

26. Miklossy J, Taddei K, Martins R, Escher G, Kraftsik R, Pillevuit O, Lepori D, Campiche M. Alzhermer disease: curly fibers and tangles in organs other than brain. J Neuropathol Exp Neurol. 1999; 58:803-814. [PubMed: 10446805]

27. Crossgrove JS, Li GJ, Zheng W. The choroid plexus removes betaamyloid from the cerebrospinal fluid. Exp Biol Med. 2005; 230:771-776.

28. Sasaki A, lijima M, Yokoo H, Shoji M, Nakazato Y. Human choroid plexus is an uniquely involved area of the brain in amyloidosis: a his-tochemicalimmunohistochmical and ultrastructural study. Brain Res. 1997; 755:193-201. [PubMed: 9175887]

29. Gu H, Wei X, Monnot AD, Fontanilla CV, Behl M, Farlow MR, Zheng W, Du Y. Lead exposure increases levels of $\beta$-amyloid in the brain and CSF and inhibits LRP1 expression in APP transgenic mice. Neurosci Lett. 2011; 490:16-20. [PubMed: 21167913]

30. Gu H, Robinson G, Hong L, Barrea R, Wei X, Farlow MR, Pushkar YN, Du Y, Zheng W. Increased $\beta$-amyloid deposition in Tg-SWDI transgenic mouse brain following in vivo lead exposure. Toxicol Lett. 2012; 213:211-219. [PubMed: 22796588]

31. Bihaqi SW, Huang $\mathrm{H}$, Wu J, Zawia NH. Infant exposure to lead $(\mathrm{Pb})$ and epigenetic modifications in the aging primate brain: implications for Alzheimer's disease. J Alzheimers Dis. 2011; 27:819833. [PubMed: 21891863]

32. Bihaqi SW, Zawia NH. Alzheimer's disease biomarkers and epigenetic intermediates following exposure to Pb in vitro. Curr Alzheimer Res. 2012; 9:555-562. [PubMed: 22272629]

33. Huang $\mathrm{H}$, Bihaqi SW, Cui L, Zawia NH. In vitro Pb exposure disturbs the balance between $\mathrm{A} \beta$ production and elimination: the role of A $\beta$ PP and neprilysin. Neurotoxicology. 2011; 32:300-306. [PubMed: 21315759]

34. Li YY, Chen T, Wan Y, Xu SQ. Lead exposure in pheochromocytoma cells induces persistent changes in amyloid precursor protein gene methylation patterns. Environ Toxicol. 2012; 27:495502. [PubMed: 22764079]

35. Wu J, Basha MR, Brock B, Cox DP, Cardozo-Pelaez F, McPherson CA, Harry J, Rice DC, Maloney B, Chen D, Lahiri DK, Zawia NH. Alzhermer's disease (AD)-like pathology in aged monkeys after infatile exposure to environmental metal lead $(\mathrm{Pb})$ : evidence for a developmental origin and environmental link for AD. J Neurosci. 2008; 28:3-9. [PubMed: 18171917]

36. Jiang YM, Long LL, Zhu XY, Zheng H, Fu X, Ou SY, Wei DL, Zhou HL, Zheng W. Evidence for altered hippocampal volume and metabolites in workers occupationally exposed to lead: a study by magnetic resonance imaging and $1 \mathrm{H}$ magnetic resonance spectroscopy. Toxicol Lett. 2008; 181:118-125. [PubMed: 18692119]

37. Behl M, Zhang Y, Monnot AD, Jiang W, Zheng W. Increased beta-amyloid levels in the choroid plexus following lead exposure and the involvement of low-density lipoprotein receptor protein-1. Toxicol Appl Pharmacol. 2009; 240:245-254. [PubMed: 19501112]

38. Behl M, Zhang Y, Shi Y, Cheng J, Du Y, Zheng W. Lead-induced accumulation of beta-amyloid in the choroid plexus: role of low density lipoprotein receptor protein-1 and protein kinase $\mathrm{C}$. Nuerotoxicology. 2010; 31:524-532.

39. Behl M, Zhang Y, Zheng W. Involvement of insulin-degrading enzyme in the clearance of betaamyloid at the blood-CSF barrier: consequences of lead exposure. Cerebrospinal Fluid Res. 2009; 6:11. [PubMed: 19747378]

40. Zheng W, Zhao Q. Establishment and characterization of an immortalized Z310 choroidal epithelial cell line from murine choroid plexus. Brain Res. 2002; 958:271-380.

41. Guo L, Lichten LA, Ryu MS, Liuzzi JP, Wang F, Cousins RJ. STAT5-glucocorticoid receptor interaction and MTF-1 regulate the expression of ZnT2 (Slc30a2) in Pancreatic acinar cells. Proc Natl Acad Sci USA. 2010; 107:2818-2813. [PubMed: 20133611] 
42. Leung KW, Liu M, Xu X, Seiler MJ, Barnstable CJ, Tombran-Tink J. Expression of ZnT and ZIP zinc transporters in the human RPE and their regulation by neurotrophic factors. Invest Ophthalmol Vis Sci. 2008; 49:1221-12231. [PubMed: 18326752]

43. Pfaffl MW, Windisch W. Influence of zinc deficiency on the mRNA expression of zinc transporters in adult rats. J Trace Elem Med Biol. 2003; 17:97-106. [PubMed: 14531638]

44. Shi LZ, Zheng W. Early lead exposure increases the leakage of the blood-cerebrospinal fluid barrier, in vitro. Human ExpToxicol. 2007; 25:159-167.

45. Shi LZ, Wang SZ, Li GJ, Zheng W. Use of Z310 cells as an in vitro blood-cerebrospinal fluid barrier model: tight junction proteins and transport properties. Toxicol In Vitro. 2008; 22:190-199. [PubMed: 17825520]

46. Wang XQ, Li GJ, Zheng W. Efflux of iron from the cerebrospinal fluid to the blood at the bloodCSF barrier: effect of manganese exposure. Exp Biol Med. 2008; 233:1561-1571.

47. Shi LZ, Zheng W. Establishment of an in vitro brain barrier epithelial transport system for pharmacological and toxicological study. Brain Res. 2005; 1057:37-48. [PubMed: 16126179]

48. Monnot AD, Behl M, Ho S, Zheng W. Regulation of brain copper homeostasis by the brain barrier systems: effects of Fe-overload and Fe-deficiency. Toxicol Appl Pharmacol. 2011; 256:249-257. [PubMed: 21315754]

49. Palmiter RD, Cole TB, Findley SD. ZnT2, a mammalian protein that confers resistance to zinc by facilitating vesicular sequestration. EMBO J. 1996; 15:1784-1791. [PubMed: 8617223]

50. Eide D. Zinc transporters and the cellular trafficking of zinc. Biochem Biophys Acta. 2006; 1763:711-722. [PubMed: 16675045]

51. Helleher SL, Lönnerdal B. Zn transporter levels and localization change throughout lactation in rat mammary gland and are regulated by Zn in mammary cells. J Nutr. 2003; 133:3378-3385. [PubMed: 14608047]

52. Belloni-Olivi L, Marshall C, Laal B, Andrews GK, Bressler J. Localization of zip1 and zip4 mRNA in the adult rat brain. J Neurosci Res. 2009; 87:3221-3230. [PubMed: 19530166]

53. Wang ZY, Stoltenberg M, Jo SM, Huang L, Larsent A, Dahlström A, Danscher G. Dynamic zinc pools in mouse choroid plexus. Neuroreport. 2004; 15:1801-1804. [PubMed: 15257151]

54. Chi ZH, Wang X, Wang ZY, Gao HL, Dahlstrom A, Huang L. Zinc transporter 7 is located in the cis-Golgi apparatus of mouse choroid epithelial cells. Neuroreport. 2006; 17:1807-1811. [PubMed: 17164669]

55. Bobilya DJ, Gauthier NA, Karki S, Olley B, Thomas WK. Longitudinal changes in zinc tansport kinetics, metallotionein, and zinc transporter expression in a bloodbrain momdel in response to a moderately excessive zinc environment. J Nutr Biochem. 2008; 19:129-137. [PubMed: 18061429]

56. Gasiorowski K, Pawlowski T, Spychala J, Swiatek J, Kozlowski H. The influence of subcutaneously administered lead (II) acetate on the concentrations of copper, iron, and zinc in the blood, kidney, liver, and spleen of rats. Sci Total Environ. 1987; 64:117-123. [PubMed: 3589658]

57. Pizent A, Jurasovic' J, Telisman S. Serum calcium, zinc, and copper in relation to biomarkers of lead and cadmium in men. J Trace Elem Med Biol. 2003; 17:199-205. [PubMed: 14968933]

58. Victery W, Miller CR, Zhu SY, Goyer RA. Effect of different levels and periods of lead exposure on tissue levels and excretion of lead, zinc and calcium in the rat. Fundam Appl Toxicol. 1987; 8:506-516. [PubMed: 3609537]

59. Dioka CE, Orsakwe OE, Adeniyi FA, Meludu SC. Liver and renal function tests in artisans occupationally exposed to lead in mechanic village in Nnewi, Nigeria. Int J Environ Res Public Health. 2004; 1:21-25. [PubMed: 16696177]

60. Malekirad AA, Oryan S, Fani A, Babapor V, Hashemi M, Baeeri M, Bayrami Z, Abdollahi M. Study on clinical and biochemical toxicity biomarkers in a zinc-lead mine workers. Toxicol Ind Health. 2010; 26:331-337. [PubMed: 20371635]

61. Flora SJ, Bhattacharya R, Sachan SR. Dose-dependent effects of zinc supplementation during chelation of lead in rats. Pharmacol Toxicol. 1994; 74:330-333. [PubMed: 7937565]

62. Lauwerys R, Roels H, BUchet JP, Bernard AA, Verhaeven L, Konings J. The influence of orallyadministered vitamin $\mathrm{C}$ or zinc on the absorption of and the biological response to lead. $\mathrm{J}$ Occup Health. 1983; 25:668-678.

63. Mahaffey KR. Nutritional factors in lead poisoning. Nutr Rev. 1981; 39:353-362. 
64. Miller GD, Massaro TF, Massaro EJ. Interactions between lead and essential elements: a review. Neurotoxicology. 1990; 11:99-120. [PubMed: 2197580]

65. Franklin PA, Pullen RGL, Hall GH. Bloodbrain exchange routes and distribution of ${ }^{65} \mathrm{Zn}$ in rat brain. Neurochem Res. 1992; 17:767-771. [PubMed: 1641058]

66. Pullen RGL, Franklin PA, Hall GH. ${ }^{65}$ Zinc uptake from blood into brain and other tissues in the rat. Neurochem Res. 1990; 15:1003-1008. [PubMed: 2077425]

67. Blair-West JR, Denton DA, Gibson AP, KcKinely MJ. Opening the bloodbrain barrier to zinc. Brain Res. 1990; 507:6-10. [PubMed: 2302580]

68. Hershey CO, Hershey LA, Varnes A, Vibhakar SD, Lavin P, Strain WH. Cerebrospinal fluid trace element content in dementia: clinical, radiologic, and pathologic correlations. Neurology. 1983; 33:1350-1353. [PubMed: 6684234]

69. Palm R, Strand T, Hallmans G. Zinc, total protein and albumin in CSF of patients with cerebrovascular diseases. Acta Neurol Scand. 1986; 74:308-313. [PubMed: 3811837]

70. Takeda A, Akiyama T, Sawashita J, Okada S. Brain uptake of trace metals, zinc and manganese, in rats. Brain Res. 1994; 640:341-344. [PubMed: 8004463]

71. Takeda A, Ishiwatari S, Okada S. Influence of transferrin on manganese uptake in rat brain. J Neurosci Res. 2000; 59:542-552. [PubMed: 10679794]

72. Takeda A, Sawashita J, Okada S. Localization in rat brain of the trace metals, zinc and manganese, after intracerebroventricular injection. Brain Res. 1994; 658:252-254. [PubMed: 7834348]

73. Constantinidis J. Hypothesis regarding amyloid and zinc in the pathogenesis of Alzheimer disease: potential for preventive intervention. Alzhermer Dis Assoc Disord. 1991; 5:31-35.

74. Constantinidis J. The hypothesis of zinc deficiency in the pathogenesis of neurofibrillary tangles. Med Hypotheses. 1991; 35:319-323. [PubMed: 1943884] 
(A) ZnT2

DIC

Merge
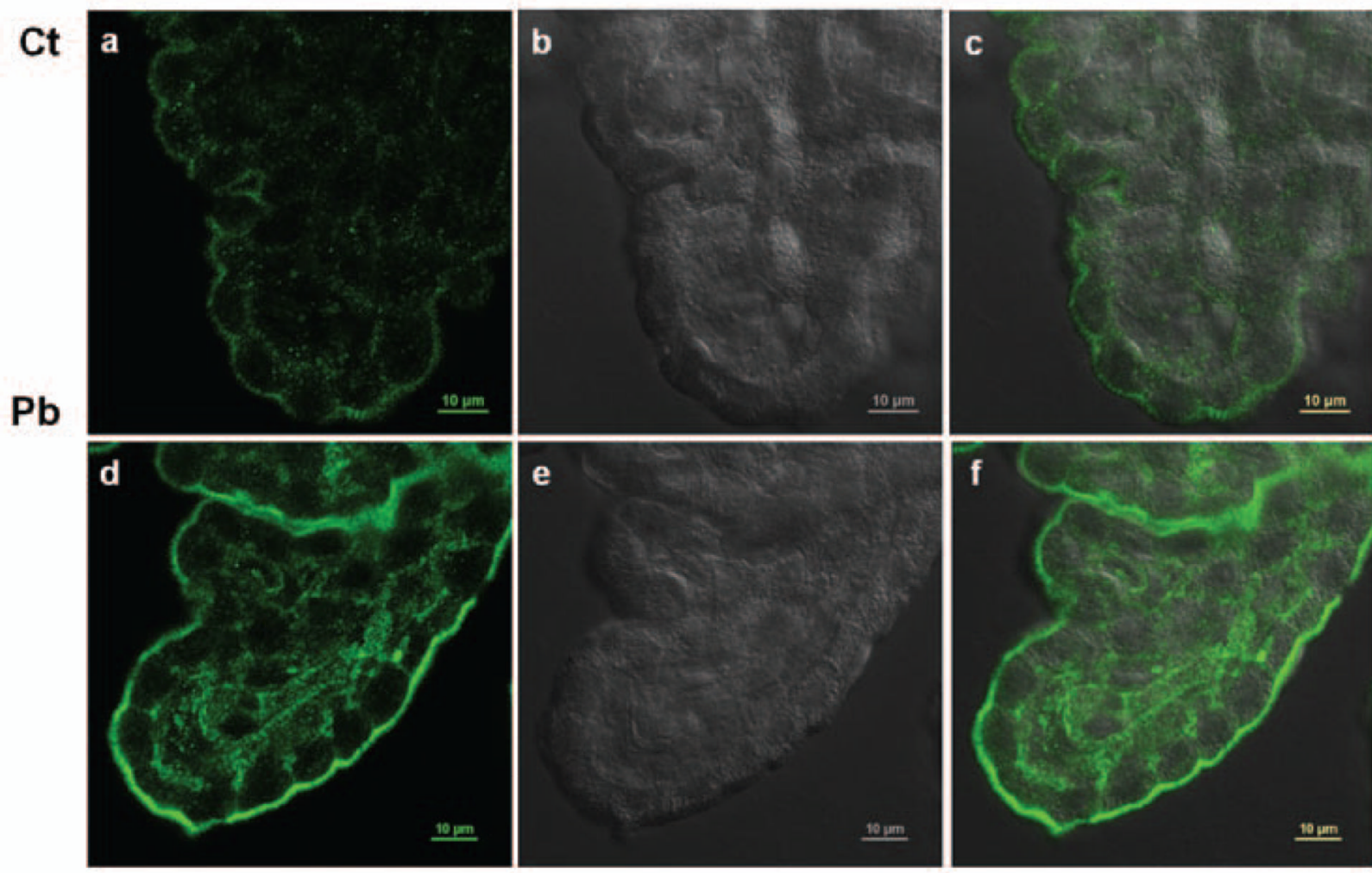

(B)

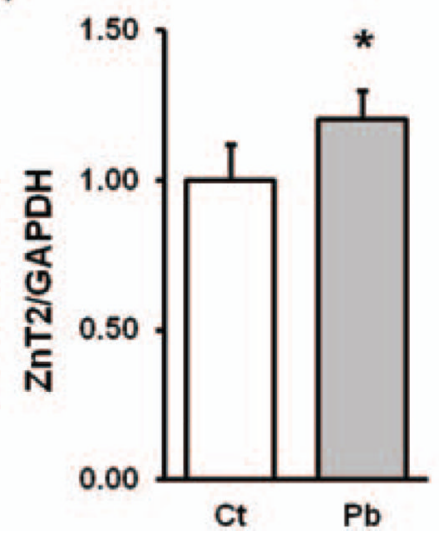

(C)

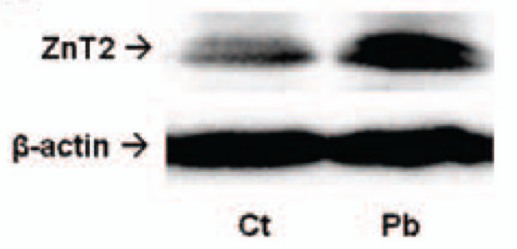

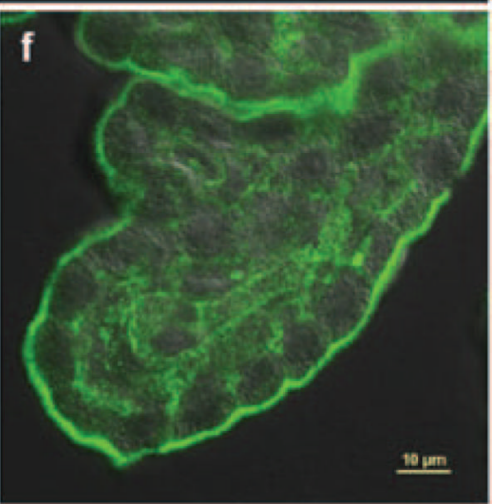

(D)

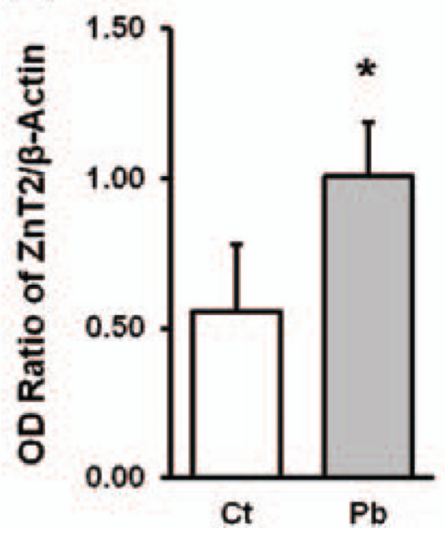

Figure 1.

Expression of $\mathrm{ZnT} 2$ in choroid plexus tissue and effect of $\mathrm{Pb}$ exposure. $\mathrm{A}(\mathrm{a}-\mathrm{c})$. Choroid plexus tissues were dissected from the lateral ventricles. $\mathrm{A}(\mathrm{d}-\mathrm{f})$. For in vivo $\mathrm{Pb}$ exposure, animals received a single ip injection of $50 \mathrm{mg} \mathrm{PbAc}$ for $24 \mathrm{~h}$. A(a) and A(d) show the ZnT2 green fluorescent signal; $\mathrm{A}(\mathrm{b})$ and $\mathrm{A}(\mathrm{c})$ show the DIC mages; $\mathrm{A}(\mathrm{c})$ and $\mathrm{A}(\mathrm{f})$ are the merged images of ZnT2 fluorescent signal and DIC. (B) qPCR quantitation of ZnT2 mRNA expression in the choroid plexus. Data represent mean $\pm \mathrm{SD}, n=6, * P<0.05$, as compared with the control. (C) Western blot analysis of $\mathrm{ZnT} 2$ in the choroid plexus. $\beta$-actin was used as the house-keeping protein. (D) Quantification of western blot was expressed as the OD 
ratio of $\mathrm{ZnT} 2 / \beta$-actin. Data represent mean $\pm \mathrm{SD}, n=3$, $* P<0.05$ as compared with the control. (A color version of this figure is available in the online journal.) 
(A)
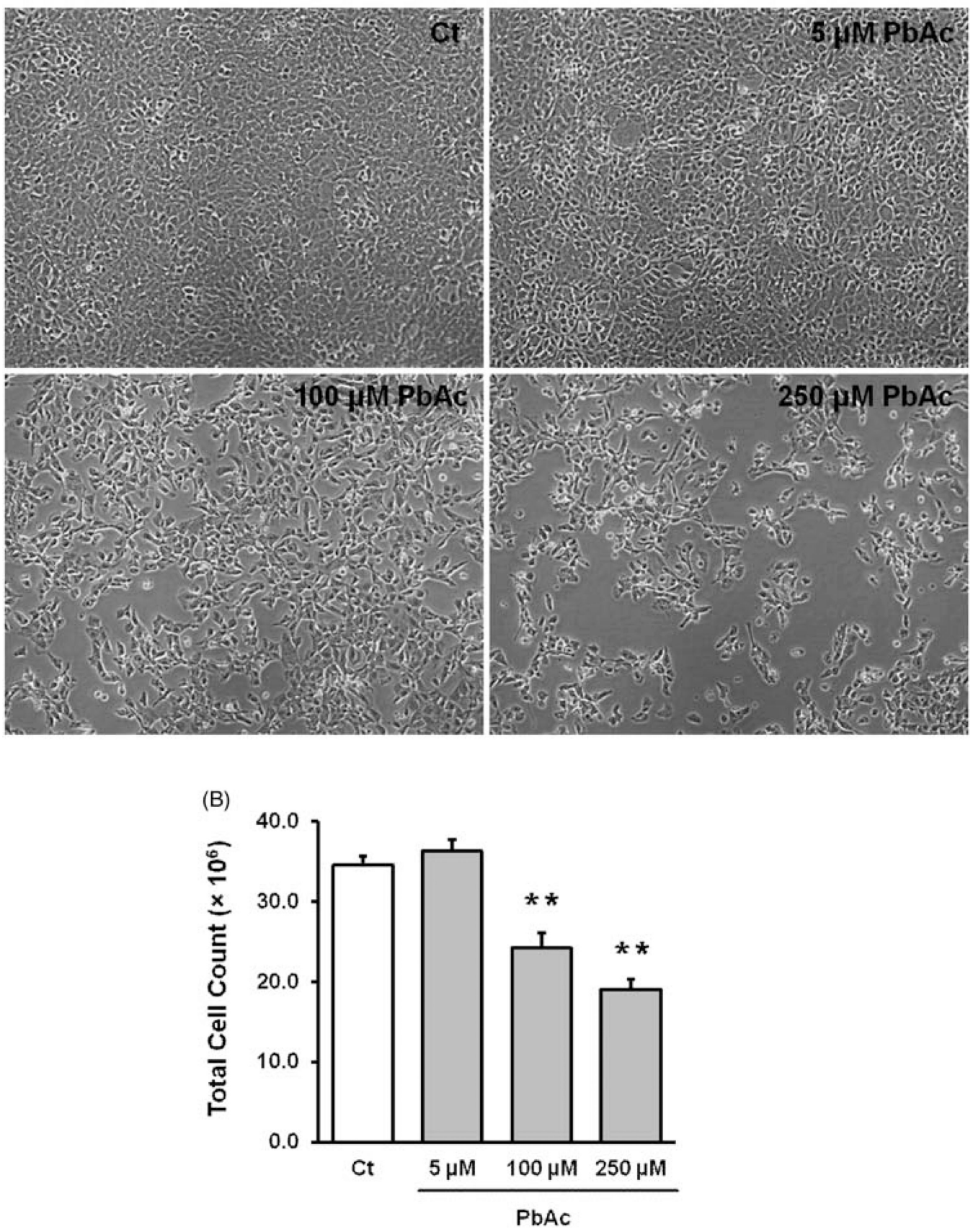

Figure 2.

Effect of Pb exposure on cultured Z3310 cells. (A) Cells were treated with 5,100, and 250 $\mu \mathrm{M} \mathrm{Pb}$ for $24 \mathrm{~h}$. The cell morphology appeared normal in the $5 \mathrm{mM} \mathrm{Pb}$ group, while the cell numbers were visibly lower in higher Pb dose groups. (B) Dose-response relationship between $\mathrm{Pb}$ treatment and total cell counts. Data represent mean $\pm \mathrm{SD}, n=6, * * P<0.01$ as compared with the control 
(A) ZnT2

DIC

Merge
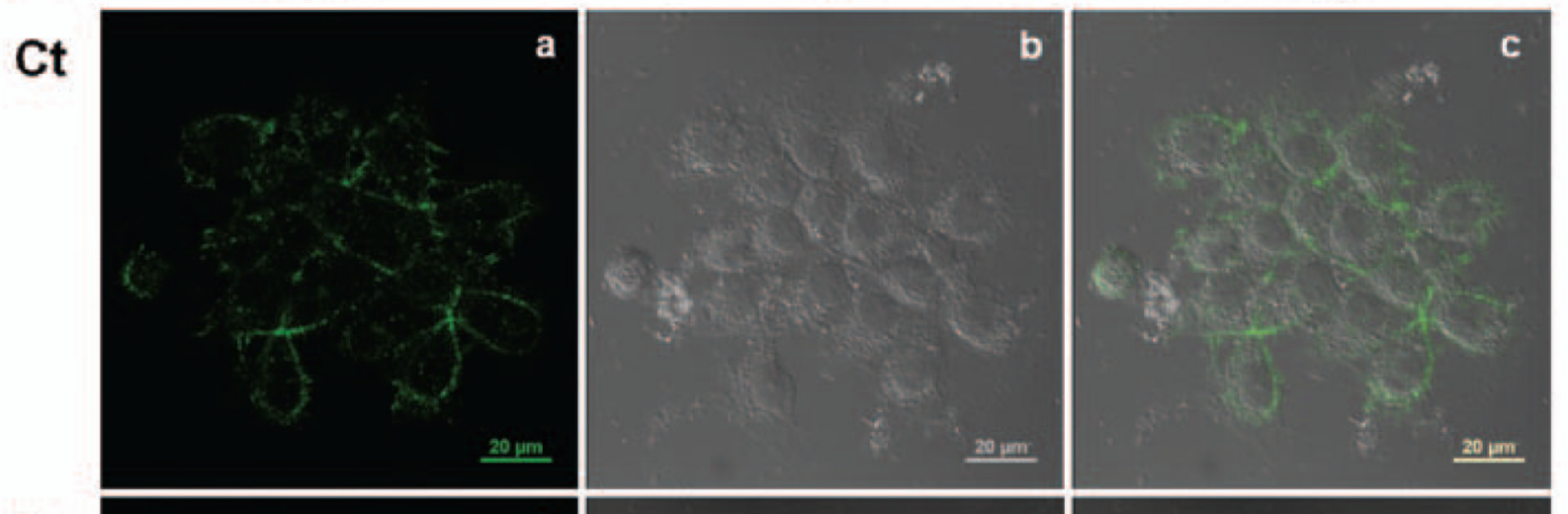

$\mathrm{Pb}$
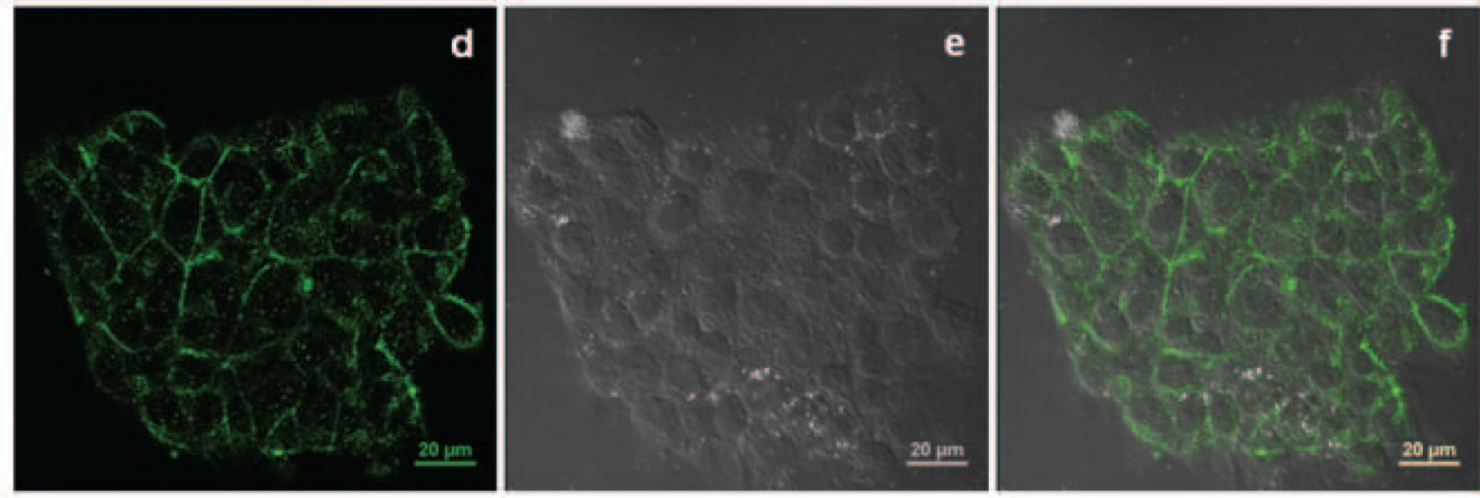

(B)

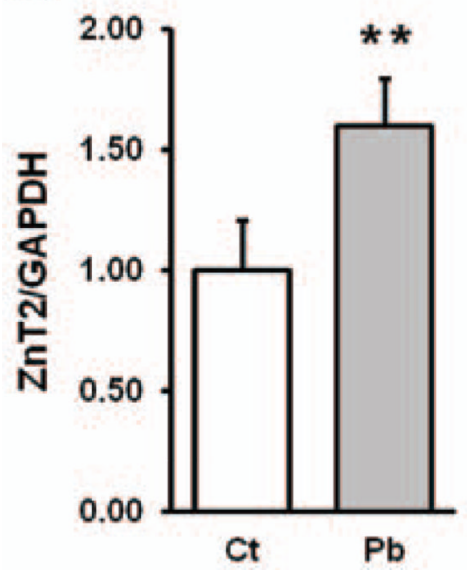

(C)

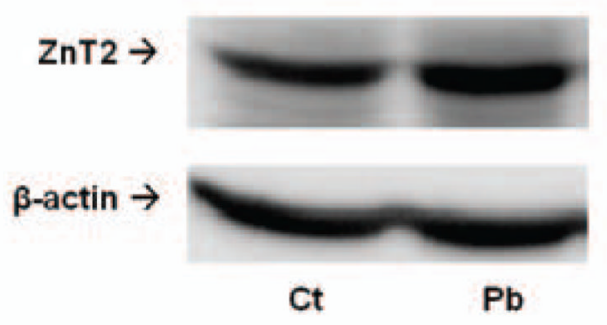

(D)

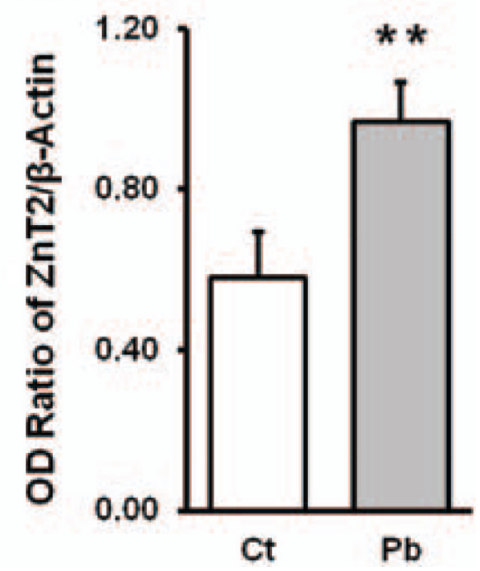

Figure 3.

Presence of ZnT2 in choroidal Z310 cells and effect of $\mathrm{Pb}$ exposure. A(a-c)) Control cells; $\mathrm{A}(\mathrm{d}-\mathrm{f}) \mathrm{Pb}$-treated Z310 cells. A(a) and A(d) show the ZnT2 green fluorescent signal; A(b) and $\mathrm{A}(\mathrm{c})$ show the DIC images; $\mathrm{A}(\mathrm{c})$ and $\mathrm{A}(\mathrm{f})$ are the merged images of $\mathrm{ZnT} 2$ fluorescent signal and DIC. (B) qPCR quantitation of ZnT2 mRNA expression. Data represent mean \pm $\mathrm{SD}, n=6, * * P<0.01$ as compared with the control. (C) Western blot analysis of ZnT2 in Z310 cells. $\beta$-actin was used as the internal control. (D) Western blot quantification. Data represent mean $\pm \mathrm{SD}, n=3, * P<0.01$, as compared with the control. (A color version of this figure is available in the online journal.) 


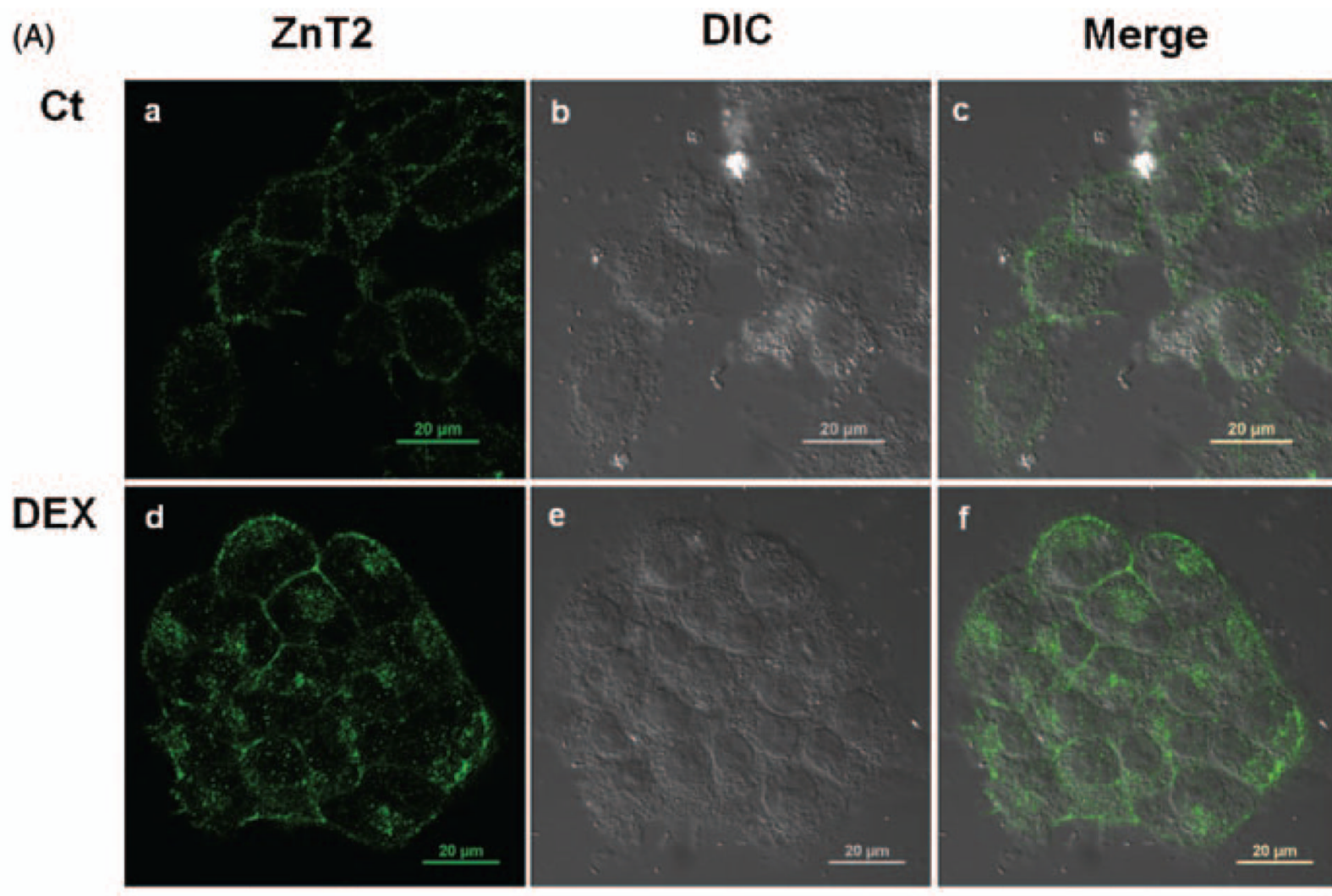

(B)

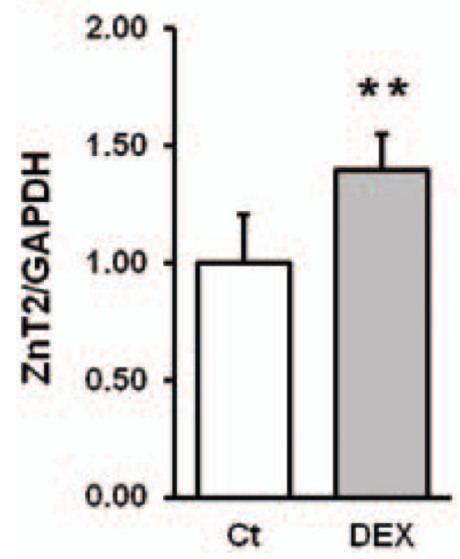

(C)

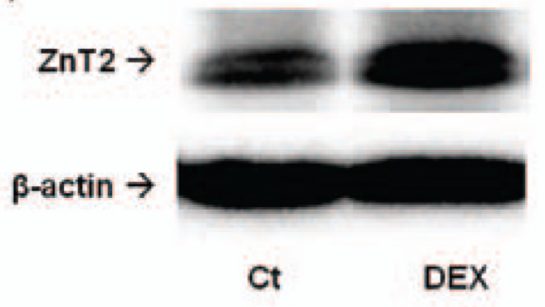

(D)

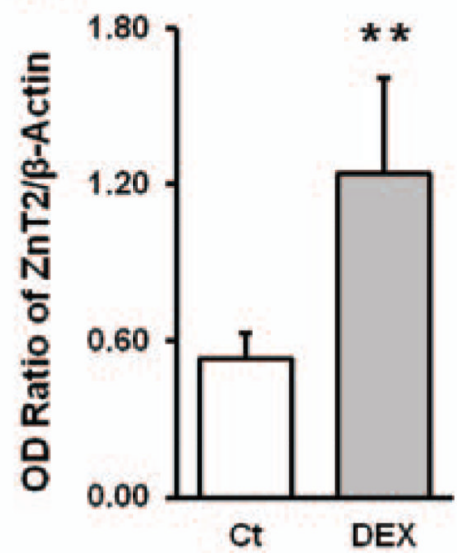

Figure 4.

Upregulation of ZnT2 following DEX exposure. A(a-c)Control images; A(d-f) Pb-treated Z310 cells. A(a) and A(d) show the ZnT2 green fluorescent signal; A(b) andA(c) show the DIC images; A(c) and A(f) are the merged images of ZnT2 fluorescent signal and DIC. (B) qPCR result of increased ZnT2 mRNA expression following DEX exposure. Data represent mean $\pm \mathrm{SD}, n=6$, $* * P<0.01$ as compared with the control. (C) Western blot result of ZnT2 and $\beta$-actin. (D) Quantification of western blot. Data represent mean $\pm \mathrm{SD}, n=4, * P<0.01$, as compared with the control. (A color version of this figure is available in the online journal.) 

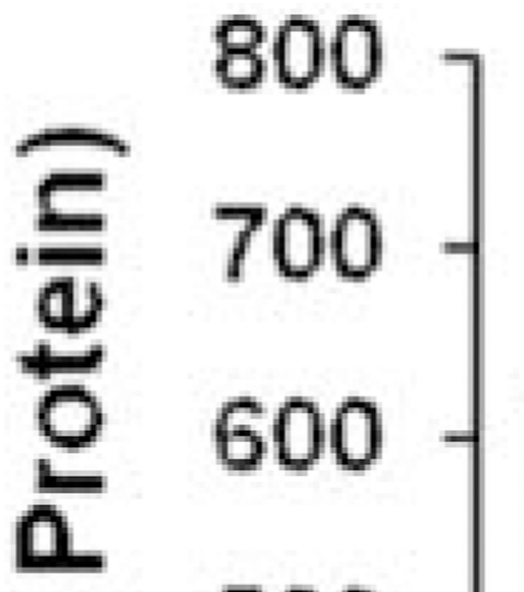

-

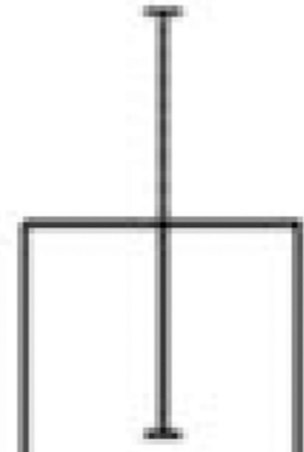

k $\star$
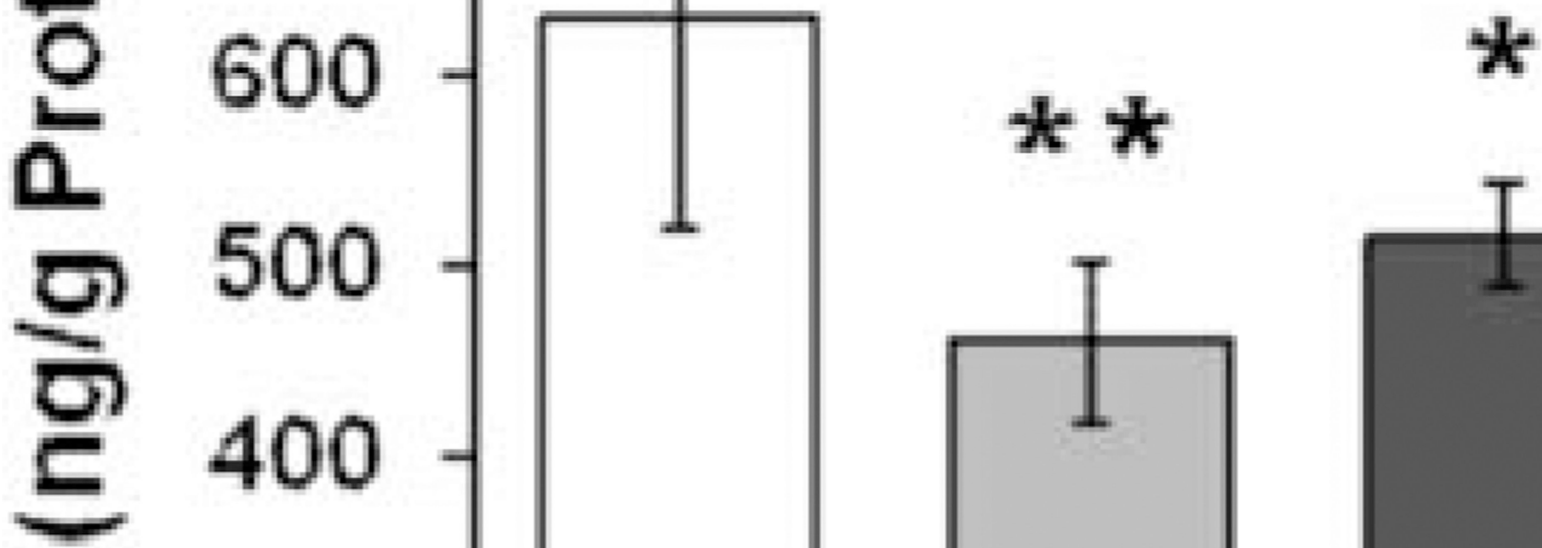

500
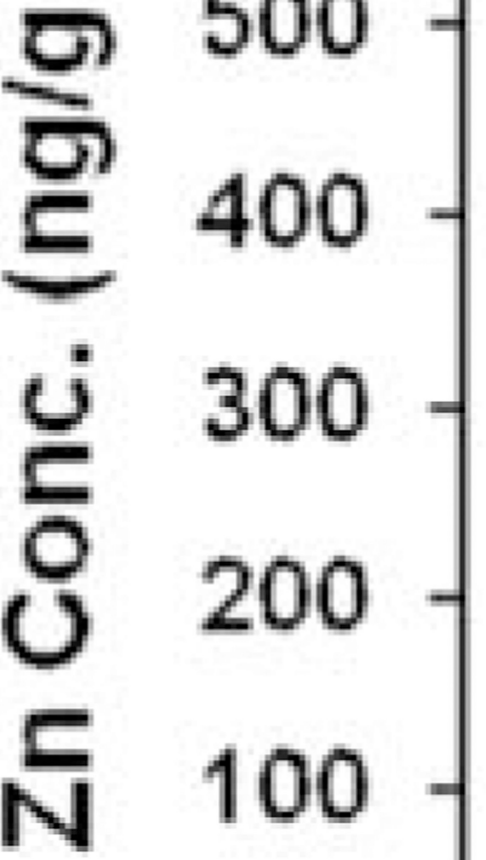

100
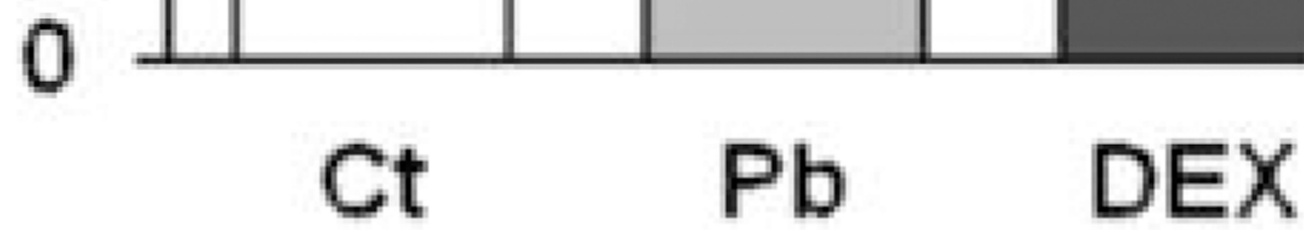

Figure 5.

Decreased intracellular Zn level following Pband DEX exposure. Cells were incubated $5 \mu \mathrm{M}$ $\mathrm{PbAc}$ and $100 \mathrm{nM}$ DEX for $24 \mathrm{~h}$ followed by $1 \mathrm{~h}$ incubation with $3 \mu \mathrm{M} \mathrm{ZnCl}_{2}$. The intracellular $\mathrm{Zn}$ concentration was determined by AAS. Result shows the intracellular $\mathrm{Zn}$ concentrations (ng $\mathrm{Zn} / \mathrm{g}$ protein) in the control, $\mathrm{Pb}$ - and $\mathrm{DEX}$-treated groups. Data represent $\mathrm{MD} \pm \mathrm{SD}, n=6, * P<0.05, * * P<0.01$, as compared with the control 

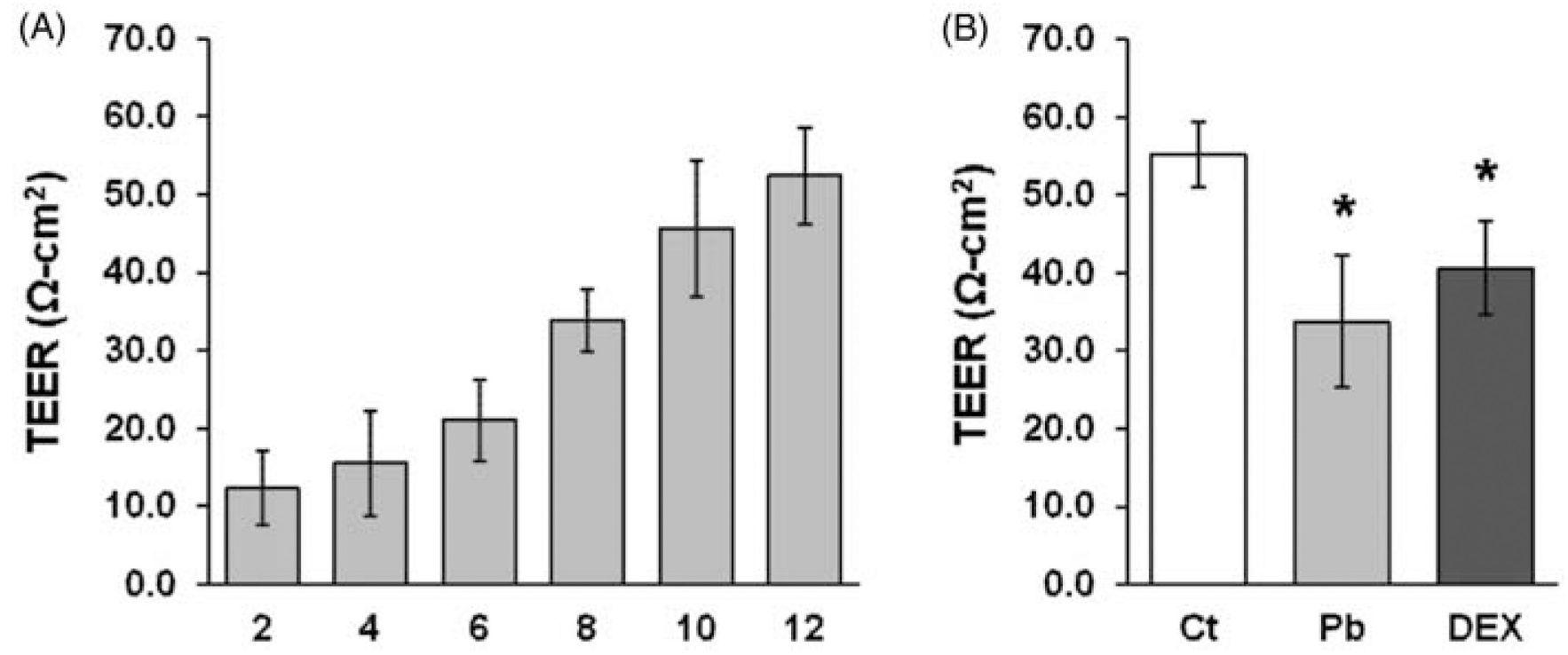

Figure 6.

Transwell permeability as affected by treatment of $\mathrm{Pb}$ and DEX. (A) Primary choroid plexus epithelial cells were cultured in the inner chamber of the Transwell device for 12 days and the TEER values were measured to track the formation of the monolayer. (B) After the monolayer barrier was formed, the primary cells were treated with $5 \mu \mathrm{M} \mathrm{PbAc}$ and $100 \mathrm{nM}$ DEX for $24 \mathrm{~h}$. At the end of the treatment, the TEER values were measured. Data represent $\mathrm{MD} \pm \mathrm{SD}, n=4-6, * P<0.05$, as compared with the control. 
Table 1

$\mathrm{P}_{\mathrm{E}}$ values and $\mathrm{P}_{\mathrm{E}}$ ratio of $\mathrm{Zn}$ and ${ }^{14} \mathrm{C}$-sucrose in transwell efflux transport studies

\begin{tabular}{llll}
\hline & \multicolumn{2}{l}{$\mathbf{P}_{\mathbf{E}}\left(\times \mathbf{1 0}^{-\mathbf{4}} \mathbf{c m} / \mathbf{m i n}\right)$} & $\mathbf{P}_{\mathbf{E}}$ ratio \\
\cline { 2 - 4 } Group & ${ }^{\mathbf{1 4}} \mathbf{C}$-sucrose & $\mathbf{Z n} \mathbf{C}$-sucrose $)$ \\
\hline Control & $12.24 \pm 0.66$ & $18.34 \pm 2.26$ & $1.50 \pm 0.08$ \\
$\operatorname{PbAc}(5 \mu \mathrm{M})$ & $12.54 \pm 0.27$ & $35.50 \pm 6.83^{*}$ & $2.83 \pm 0.31^{*}$ \\
$\operatorname{DEX}(100 \mathrm{nM})$ & $12.43 \pm 0.51$ & $25.65 \pm 6.79^{* *}$ & $2.06 \pm 0.24^{* *}$ \\
\hline
\end{tabular}

Note: Data represent mean $\pm \mathrm{SD} n=4-6$,

${ }^{*} P<0.01$,

${ }_{P}^{* *}<0.05$ as compared to the control. Treatment conditions are described in the Methods section. 